\title{
POTENSI PRODUKSI HIJAUAN Mikania cordata SEBAGAI PAKAN TERNAK RUMINANSIA DI PROVINSI BALI
}

\author{
I Wayan Suarna dan Ni Nyoman Suryani \\ Puslitbang Tumbuhan Pakan Universitas Udayana \\ puslitbangtp@gmail.com dan suarnawyn@yahoo.com
}

\begin{abstract}
ABSTRAK
Identifikasi tumbuhan pakan potensial dari berbagai sumberdaya hayati tumbuhan pakan telah menjadi kebutuhan vital dalam rangka peningkatan produksi hijauan pakan. Sebuah penelitian telah dilaksanakan bertujuan untuk mengetahui potensi produksi hijauan Mikania cordata dan potensi pengembangannya sebagai tumbuhan pakan ternak. Metode penelitian yang digunakan yaitu survei langsung di lapangan terhadap keberadaan Mikania cordata di seluruh kabupaten di Bali. Hasil survei menunjukkan bahwa produksi Mikania cordata adalah sebesar $840 \mathrm{~kg} \mathrm{ha}^{-1}$ dengan kadar air yang cukup tinggi. Mikania sangat mudah menyebar dan sangat menyukai naungan serta dapat tumbuh baik pada lahan tanpa nanungan. Hampir di semua kabupaten di Bali dapat dijumpai tanaman Mikania. Mikania telah banyak dimanfaatkan peternak sebagai pakan yang dicampur dengan berbagai rumput lokal. Disimpulkan bahwa Mikania cordata sangat potensial sebagai sumber hijauan pakan, mudah dikembangkan dalam berbagi pola integrasi tanaman dan produksinya tinggi.
\end{abstract}

Kata kunci: Mikania cordata, identifikasi, dan produksi hijauan

\begin{abstract}
Identification of potential forage variety from various biological resources of forages has become a vital need in order to increase forage production. A study has been carried out aimed to finding out the potential forage production of Mikania cordata and its development potential as tropical forage. The research method used is a field survey of the presence of Mikania cordata in all regencies in Bali. The survey results show that the production of Mikania cordata is $840 \mathrm{~kg} \mathrm{ha}^{-1}$ with a high water content. Mikania is very easy to spread and is very fond of shade and can grow well on non-humid land. Almost all districts in Bali can find Mikania plants. Mikania has been widely used by farmers as feed mixed with various local grasses. It was concluded that Mikania cordata is very potential as a source of forage feed, easily developed in sharing patterns of crop integration and high production.
\end{abstract}

Keywords: Mikania cordata, identification, and forage production

\section{PENDAHULUAN}

Pemerintah Indonesia saat ini sedang menggalakkan Upaya Khusus Sapi Indukan Wajib Bunting yang disingkat dengan Upsus Siwab. Program khusus terhadap peningkatan produktivitas ternak ruminansia (sapi induk) membawa konsekuensi logis dibutuhkannya ketersediaan pakan hijauan yang berkualitas sebagai sumber pakan utama ternak ruminansia. Sementara, selama ini perhatian terhadap keberadaan tumbuhan penghasil hijauan pakan masih sangat kurang.

Di Bali, potensi pengembangan tumbuhan pakan masih cukup luas terutama pada lahan kering dan lahan di bawah tanaman perkebunan. Luas Lahan Kering di Provinsi Bali pada tahun 2008 adalah 78.129,89 ha atau $13.86 \%$ dari luas daratan Pulau Bali tersebar di berbagai kabupaten dan kota (Suarna, 2009). Lahan kering seperti tegalan sering diusahakan untuk penanaman kedelai, jagung, tanaman hortikultura, serta tumbuhan pakan. Pemanfaatan lahan kering untuk penanaman tumbuhan pakan masih belum banyak dilakukan. Penutupan vegetasi pada lahan kering selain akan meningkatkan ketersediaan pakan. Juga dapat meningkatkan penyerapan gas rumah kaca (GRK) untuk meminimalisasi efek pemanasan global. Pada pertanian lahan kering, eksistensi subsektor peternakan (untuk budidaya tumbuhan pakan tropik) lebih menonjol dibandingkan dengan subsektor tanaman pangan, sehingga dengan demikian semestinya sub-sektor peternakan mendapatkan perhatian yang lebih baik.

Tumbuhan pakan selain dapat dikembangkan 
dengan berbagai model, tumbuhan pakan juga memiliki beragam manfaat (multiguna) antara lain adalah: sebagai sumber plasma nutfah, penyedia hijauan pakan, tumbuhan penutup tanah (cover crop), konservasi lahan, mitigasi dan adaptasi terhadap perubahan iklim, 5 mencegah banjir dan erosi, bahan industri kerajinan rumah tangga, dan 7) pengisi lansekap pertamanan, median jalan, dan lapangan golf. Dari uraian di atas dapat diformulasikan bahwa permasalahan pengembangan tumbuhan pakan adalah masih kurangnya perhatian masyarakat terhadap pengembangan tumbuhan pakan dalam berbagai model, fungsi, dan manfaat serta belum optimalnya pemanfaatan berbagai jenis lahan yang potensial terhadap pengembangan tumbuhan pakan. Mempertimbangkan latar belakang di atas artikel ini ditujukan untuk mengetahui sejauh mana potensi produksi hijauan Mikania cordata sebagai salah satu sumber bahan pakan ternak ruminansia di Provinsi Bali.

\section{MATERI DAN METODE}

Penelitian ini merupakan penelitian survei dengan menggunakan data langsung di lapangan. Dalam penelitian ini Bali dikelompokkan atas 5 daerah iklim, 7 jenis tanah dan 5 jenis penggunaan lahan. Ketiga faktor tersebut sangat besar pengaruhnya terhadap penyediaan hijauan pakan. Dengan demikian pengambilan sampel didasarkan atas peta unit lahan yang disusun dengan menumpangtindihkan ketiga peta tersebut (peta iklim, peta jenis tanah, dan peta tataguna lahan). Untuk mencerminkan penyediaan hijauan selama setahun, maka sampel akan diambil minimal sebanyak dua kali yakni pada bulan-bulan yang merepresikan musim hujan dan musim kemarau. Variabel yang diamati adalah karakteristuk tanaman, produksi hijauan, komposisi botani hijauan dan potensinya sebagai sumber bahan pakan ternak. Komposisi botani diukur dengan metode Dry Weight Rank Methode (t’Mannetje \& Haydock, 1963).

\section{HASIL DAN PEMBHASAN}

Dalam rangka meningkatkan peranan tumbuhan pakan, meningkatkan efisiensi pemanfaatan lahan dan sebagai upaya berperan aktif dalam program mitigasi dan adaptasi terhadap perubahan iklim sangat diperlukan pemikiran tentang peranan dan strategi pengembangan tumbuhan pakan di Provinsi Bali. Pengembangan tumbuhan pakan sangat bergayut dengan kebijakan yang bernuansa nasional seperti: SDGs (Tujuan 13, 14 DAN 15), Menuju Indonesia Hijau, Indeks Kualitas Lingkungan Hidup, Mitigasi dan Adaptasi Perubahan Iklim, dan Upsus Siwab, demikian pula bila dikaitkan dengan kebijakan ekoregion dan Daerah seperti MP3EI (Pariwisata Nasional dan Ketahanan pangan nasional), Daya Dukung Lingkungan, perluasan kawasan bervegetasi, Bali Green Province, Bali Organik, dan Simantri. Pada dasarnya semua kebijakan tersebut menginginkan adanya peningkatan luasan dan kualitas kawasan bervegetasi dan memanfaatkan kawasan tersebut untuk menjaga dan melestarikan fungsi keseimbangan lingkungan hidup.

Hasil penelitian terhadap daya dukung lingkungan (lahan dan air) di Provinsi Bali (Tahun 2009) menunjukkan bahwa kedelapan kelas lahan ada di Bali, didominasi Kelas VI, VII dan VIII seluas $285.847,83$ ha $(50,7 \%)$, terluas adalah kelas VII $(118.479,70$ ha ) 21,1\% dengan demikian jika dilihat dari kesesuaian lahan untuk budidaya tanaman pakan yang dapat dilakukan hampir di semua tipologi kelas lahan maka potensi dan peluang budidaya tumbuhan pakan sangat besar. Kondisi eksisting tataguna lahan untuk kepentingan padang rumput di Bali hanya 9.890,60 ha $(1,75 \%)$ dan lahan terbuka seluas $18.467,66$ ha $(3,28 \%)$. Tampak jelas bahwa antara pemanfaatan lahan untuk padang rumput dibandingkan dengan dominasi kelas lahan masih sangat timpang.

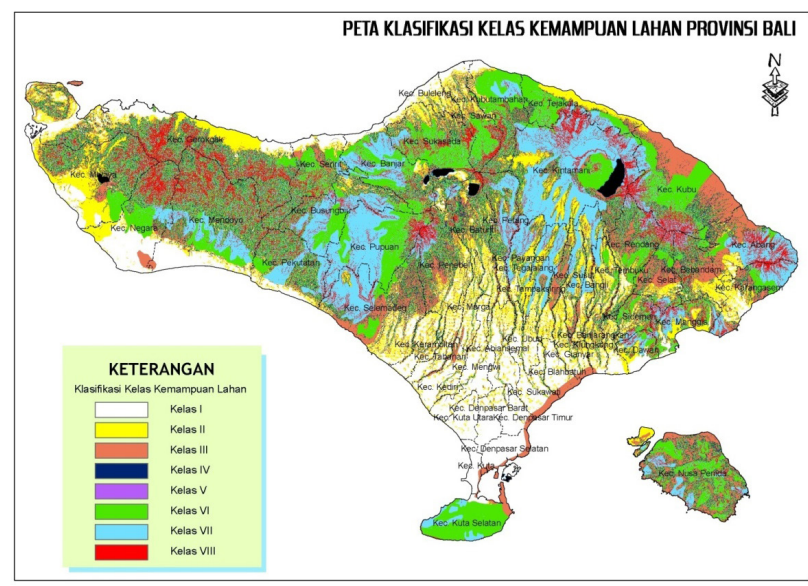

Gambar 1. Peta Klasifikasi Kelas Kemampuan Lahan di Provinsi Bali (PPLH - Unud, 2009)

Bila dilihat dari luasan lahan kering di Bali yang mencapai $13.86 \%$ dari luas daratan tampak bahwa belum banyak masyarakat yang mengadopsi hasil inovasi teknologi pengembangan hijauan pakan yang telah ditemukan oleh para ahli tanaman pakan (misalnya STS). Demikian pula halnya terhadap tumbuhan pakan yang berfungsi sebagai pencegah erosi (cover crop) dan vegetasi lansekap belum banyak dilakukan. Tumbuhan pakan yang dipergunakan untuk kepentingan lansekap saat ini antara lain adalah Arachis pintoi, Stenotaphrum secundatum, Imperata sp, Zoisea japanika, Z. matrella, Axonopus compresus, Clitoria ternatea, Cynodon dactilon, dan 
sebagainya.

Pemerintah Provinsi Bali saat ini mengembangkan berbagai program unggulan antar lain: Bali Hijau, Bali Organik, dan Simantri. Kebijakan lainnya adalah mendukung kebijakan nasional antara lain adalah: percepatan pencapaian SDGs, Menuju Indonesia Hijau, Rencana Aksi Perubahan Iklim dan sebagainya. Program unggulan dan dukungan terhadap program nasional membutuhkan perluasan kebun-kebun hijauan pakan untuk kepentingan penyediaan hijauan, konservasi lahan, dan kelestarian fungsi lingkungan hidup.

Integrasi tumbuhan pakan juga dapat dilaksanakan pada lahan perkebunan. Luasan areal dan jenis tanaman perkebunan yang ada di Provinsi Bali antara lain: kelapa dalam, kelapa hibrida, kelapa genjah, kelapa deres, kopi arabika, kopi robusta, kakao, kapok, dan karet masing-masing seluas 69.853 ha, 337 ha, 1.784 ha, 158 ha, 7.927 ha, 23.599 ha, 12.328 ha, dan 1.165 ha, sehingga jumlahnya mencapai 117.151 ha (Bali Membangun, 2007). Luasan areal perkebunan tersebut sangat potensial untuk penanaman hijauan pakan. Sementara data luasan areal rumput menurut Disnak Provinsi Bali (2007) mengalami penurunan dari 24.777.147 ha (Tahun 2003) menjadi 24.616.806 ha (Tahun 2007) atau menurun sebesar 0,65\%.

Salah satu kebijakan Pemerintah Provinsi Bali di sektor pertanian adalah melaksanakan Program Simantri dengan strategi menuju Bali Organik sehingga akan terwujud Bali Green Province. Program Simantri sebagai sebuah "sistem industri pertanian", sangat terkait dengan ternak (terutama ternak ruminansia) sebagai salah satu komponen sIstem, konsekuensinya penyediaan hijauan untuk pakan ternak ruminansia baik kualitas maupun kuantitasnya merupakan kebutuhan utama pendukung program simantri. Hal tersebut disebabkan karena hampir 70\% dari biaya untuk produksi ternak adalah biaya pakan.

Kondisi kelerengan lahan kering di Bali juga sangat bervariasi, sehingga sangat diperlukan teknologi budidaya tumbuhan pakan, yang sesuai dengan tujuan dapat memperbaiki kondisi kesuburan tanah, konservasi tanah, dan meningkatkan produktivitas tanah. Selain factor geografis di atas, di Bali terdapat pula tumbuhan pakan yang beragam baik dari jenis rumput-rumputan dan leguminosa yang memiliki potensi besar untuk dikembangkan sebagai sumber hijauan pakan. Tumbuhan pakan introduce juga telah berhasil dikembangkan pada berbagai lahan kering di Bali. Tumbuhan tersebut antara lain adalah Clitoria ternatea cv Milgara, Stenotaphrum secundatum, Arachis pintoi, Cencrus ciliaris, Panicum maximum, Paspalum dilatatum, Urochloa mozambiciences, Penisetum purpureum dan sebagainya.

Mikania cordata adalah perdu merambat yang dapat dijumpai di berbagai kawasan di Provinsi Bali. Tumbuhan ini sangat digemari oleh ternak sapi, mudah dikembangbiakkan dan produksi berat segarnya tinggi. Di berbagai tegalan atau lahan perkebunan tanaman ini tumbuh segar serta rimbun dan juga dapat berperan sebagai tumbuhan penutup tanah untuk mencegah meningkatnya transport sedimen saat terjadi hujan lebat.
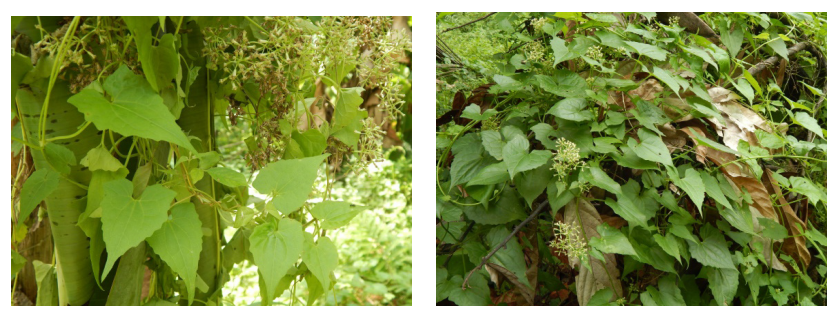

Gambar: 2. Tanaman Mikania cordata

Kingdom : Plantae

Divisi : Spermatophyta

Subdivisi : Angiospermae

Kelas : Dycotyledoneae

Ordo : Asterales

Famili : Asteraceae

Genus : Mikania

Spesies : Mikania cordata H.B.K (nama latin) Kamania (nama daerah)

Batang mikania (Mikania cordata) tumbuh menjalar berwarna hijau muda, bercabang dan ditumbuhi rambut-rambut halus. Panjang batang dapat mencapai 3-6m. Pada tiap ruas terdapat dua helai daun yang saling berhadapan, tunas baru dan bunga. Helai daun berbentuk segitiga menyerupai hati , dengan panjang daun 4-13cm, dan lebar daun 2-9cm. Permukaan daun menyerupai mangkok dengan tepi daun bergerigi, dan daun tidak lengkap. Bunga tumbuh berwarna putih, berukuran kecil dengan panjang 4.5-6 mm, dan tumbuh dari ketiak daun atau pada ujung tunas. Biji dihasilkan dalam jumlah besar, berwarna coklat kehitaman dengan panjang 2 $\mathrm{mm}$. Buah berbentuk bulat telur terbalik, berwarna hijau, berukuran $1-3 \mathrm{~mm}$, buah nya merupakan buah sejati, dan memiliki kulit biji yang tipis.

Hasil survei lapangan menunjukkan bahwa produksi Mikania cordata adalah sebesar $840 \mathrm{~kg}$ $\mathrm{ha}^{-2}$ dengan kadar air yang cukup tinggi. Hasil survei menunjukkan Mikania sangat mudah menyebar dan sangat menyukai naungan dan dapat hidup dengan baik pada lahan tanpa nanungan. Hampir di semua kabupaten di Bali dapat dijumpai tanaman mikania yang tumbuh subur. Peternak sapi telah banyak memanfaatkan sebagai pakan unggul yang pemberiannya dicampur dengan berbagai pakan dari rumput lokal.

Selain Mikania cordata juga terdapat Mikania 
micracanta yang disebut sebagai gulma introduksi. Gulma tersebut berasal dari Amerika Selatan yang pertama kali dimasukkan ke Indonesia (Bogor Botanical Garden) dari Paraguay pada tahun 1949. Pada tahun 1956 tanaman tersebut telah menyebar luas sebagai tanaman penutup tanah pada perkebunan karet (Whitten et al., 2000).

\section{SIMPULAN DAN SARAN}

Penelitian ini menyimpulkan bahwa Mikania cordata memiliki potensi yang sangat besar sebagai tanaman pakan, mudah dikembangkan dalam berbagi pola integrasi tanaman dan produksinya tinggi.

Disarankan agar kajian terhadap komponen kearifan lokal dalam pengembangan Hjauan pakan perlu dilakukan untuk memberikan dukungan dan perluasan proses difusi Ipteks tumbuhan pakan bagi masyarakat petani peternak. Diperlukan kebijakan dan dukungan pemerintah daerah sehingga peran multiguna tumbuhan pakan dapat dioptimalkan.

\section{DAFTAR PUSTAKA}

Bappeda Provinsi Bali. 2007. Bali Membangun. Badan Perencanaan Pembangunan Daerah, Provinsi Bali.

Distan Bali. 2010. Kegiatan Sistem Pertanian Terintegrasi (Simantri) di Provinsi Bali. Dinas Pertanian Tanaman Pangan Provinsi Bali, Denpasar.

Suarna, W. 2011. Peran Tanaman Pakan Dalam Mitigasi Dan Adaptasi Terhadap Perubahan Iklim. Prosiding Seminar dan Lokakarya Nasonal Tanaman Makanan Ternak Tropik. Fakultas Peternakan Universitas Udayana, Denpasar

t'Mannetje, L. And Haydock, KP. (1963). The dry weight rank method for the botanical analysis of pasturfe. Br. Gratsh. Soc. 18:268.

Whitten, T., R.E. Soeriaatmadja, S.A. Afiff. 2000. The Ecology of Java and Bali. Vol. II. Periplus Editions (HK) Ltd. 